\title{
First technological and provenance analysis on obsidian artifacts from Tafí Valley (Tucumán Province, Argentine Republic)
}

\author{
Juan M. Montegú ${ }^{1}$, Valeria L. Franco Salvi ${ }^{2}$, Julián Salazar ${ }^{3}$ \\ 1. Centro de Investigaciones de la Facultad de Filosofía y Humanidades. Universidad Nacional de Córdoba \\ (UNC). 9 de Julio 2635, Córdoba 5003, Argentina. Email: juanmontegu@ unc.edu.ar \\ 2. Instituto de Humanidades, Consejo Nacional de Investigaciones Científicas y Técnicas (CONICET) - \\ Universidad Nacional de Córdoba (UNC). Copiapó 678, Córdoba 5000, Argentina. \\ Email: valefrancosalvi@unc.edu.ar \\ 3. Centro de Estudios Histórico Prof. Carlos S. A. Segreti, Consejo Nacional de Investigaciones Científicas y \\ Técnicas (CONICET) - Universidad Nacional de Córdoba (UNC). Luis Rossi 3321, Córdoba 5016, Argentina. \\ Email: juliansalazar@ffyh.unc.edu.ar
}

\begin{abstract}
:
Regional provenance analyses of obsidian have enabled to identify so far twelve sources in Northwest of Argentina and defined two main and stable areas of distribution along the pre-Hispanic period. The aim of this paper is to report the first analyses carried out on obsidian artifacts recovered from two archaeological sites of the Tafí valley (Tucumán, Argentina), dating to the first and second millennium CE. The study addresses the sourcing and use of this raw material in their contexts, as well as the inclusion of the study area within the obsidian distribution circuits in the Northwest of Argentina. The methodology included techno-morphological and morphological-functional analyses as well as chemical provenance studies using $\mathrm{x}$-ray fluorescence (ED-XRF). The results enabled us to detect, so far, the use of the Ona-Las Cuevas source, located approximately $240 \mathrm{~km}$ far from Tafí valley in the southern puna of Argentina (Catamarca province); and to suggest the implementation of indirect procurement practices within complex distribution circuits. We have also established that the obsidian artifacts would have been used intensively in daily activities which were part of household organization, such as long-distance relationships, hunting and processing food. Based on this information, we discuss the practical uses of obsidian, as well as other possible roles of this raw material in pre-Hispanic contexts which contribute to broaden knowledge about the cultural developments of Tafí valley.
\end{abstract}

Keywords: obsidian; Tafí Valley; circulation; daily practices; pre-Hispanic contexts

\section{Introduction}

The aim of this paper is to present and comment the first analyses carried out on obsidian artifacts recovered in two archaeological sites of the Tafí valley, northwest Tucumán province, Argentine Republic (Figure 1). This type of research is scarce in the study area, so

Published by the School of History, Classics and Archaeology, University of Edinburgh ISSN: 2055-0472. URL: http://journals.ed.ac.uk/lithicstudies/ 
that the results contribute to broaden knowledge about the cultural developments of this valley.

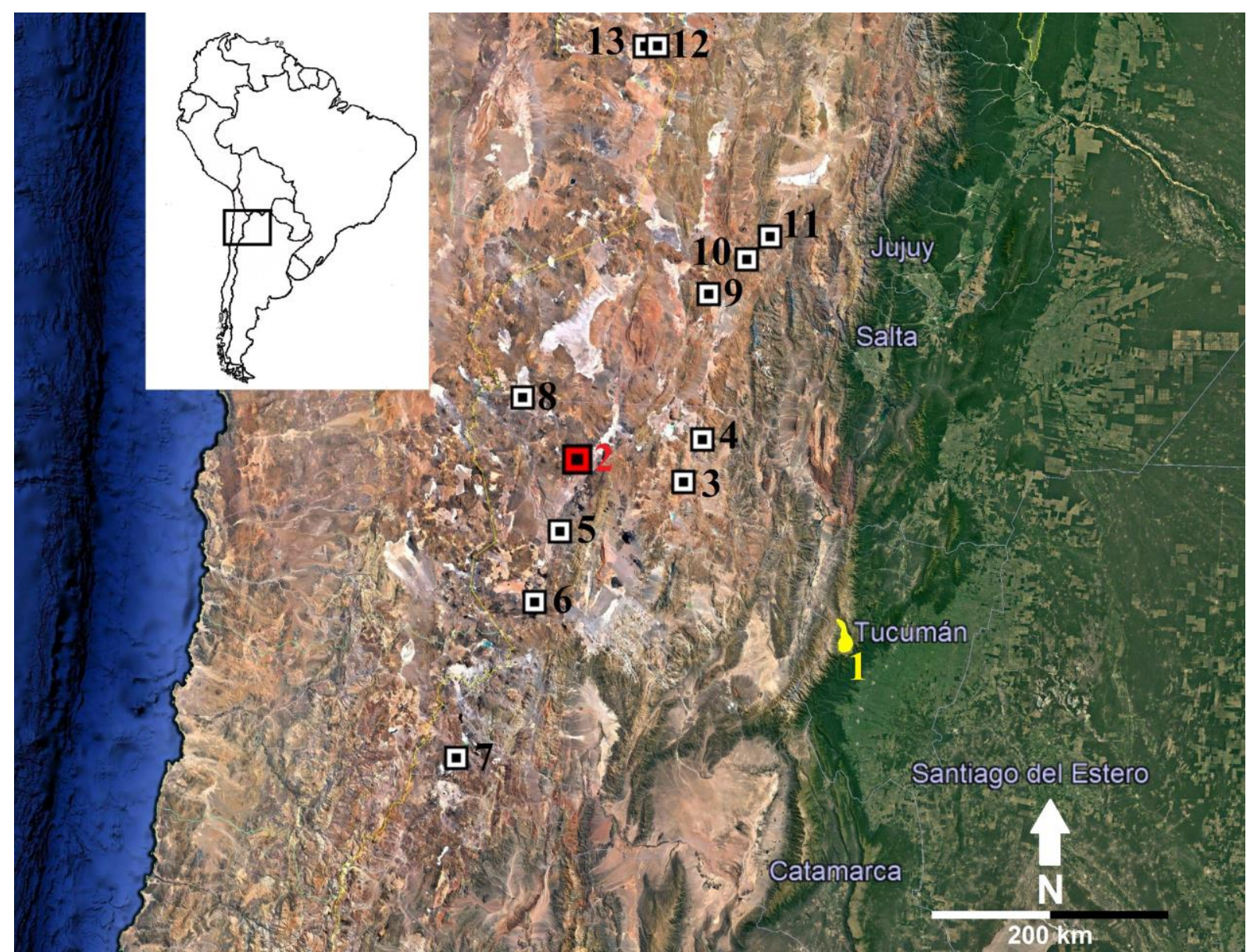

Figure 1. Location of the study area (1. Tafí Valley) and obsidian sources in Northwest Argentina (2. Ona-Las Cuevas; 3. Laguna Cavi; 4. Salar del Hombre Muerto; 5. Cueros de Purulla; 6. Chascón; 7. Valle Ancho; 8. Archibarca; 9. Quirón; 10. Alto Tocomar; 11. Ramadas; 12. Caldera Vilama 1 and 2; 13. Laguna Blanca and Zapaleri).

The study is aimed at determining the origin of obsidian artifacts recovered in stratigraphic excavations and understanding the practices of use of these materials in their archaeological contexts. Thus, an initial approach to the role of this raw material in the social reproduction of the pre-Hispanic groups in the study area and its role in the relationships with other populations of Northwest Argentina was performed.

Regional provenance analyses of obsidian have enabled to identify so far twelve sources in Northwest of Argentina (Figure 1) and defined two main and stable areas of distribution along the pre-Hispanic period from 2200 to 400 BP (Escola 2007; Yacobaccio et al. 2002; 2004). Here we highlight a source located in the southern area of the region, called Ona-Las Cuevas. It is a primary deposit which is situated in Southern Puna of Argentina, at 3700 m.a.s.l., more specifically, on the west bank of the Salar de Antofalla, in the department of Antofagasta de la Sierra, province of Catamarca (Escola 2004) (Figure 1). Obsidian from this source is a black translucent rock with variations ranging from black and gray black, changing from light gray to reddish brown (Escola \& Hocsman 2007). In the pre-Hispanic period mentioned above its range of circulation covered approximately $340 \mathrm{~km}$, being present in archaeological sites of the puna, valleys and the eastern piedmont (Escola 2007). 
Several authors highlighted the almost exclusive use of obsidian for the manufacture of small stemmed and unstemmed triangular projectile points during the early and late agropastoralist periods (Carbonelli 2014; Chaparro 2009; Escola 2000; 2007; De Feo \& Alvarez Soncini 2010; Gaál 2014; Hocsman 2006; Mercuri 2007; 2008; Montegú 2018; Moreno 2005; Palma \& Olivera 1992-1993; Salazar 2006; 2010; Somonte 2009; Wynveldt \& Flores 2014). At the same time, the social and symbolic role of circulation and use of this raw material has been proposed for the Northwest of Argentina and Patagonia (Escola 2007; Hermo 2008; Moreno 2005). Both the relationship between raw material and projectile points and the social role of obsidian will be discussed in this paper.

\subsection{Archaeological sites}

Lithic materials were collected from La Bolsa 1 (LB1) and La Bolsa 2 (LB2) (Figure 2), two archaeological sites with similar material remains. They are located in the north of Tafí valley, Northwestern Argentina, between the orographic systems of Sierras de Aconquija and Cumbres Calchaquíes, at 2500-3000 m.a.s.l. (Figure 2). Both sites include house compounds, agricultural fields, food storage features, craft production areas, and material features emphasizing kinship relations. LB1 presents chronological dating associated to the first millennium CE while LB2 presents a dating during the first half of the second millennium CE. During the first millennium CE, the earliest village settlements in the valley started to grow based in sedentary settlements systems, agropastoral economies and technology developments (e.g., pottery) (Salazar 2010). In the first half of the second millennium A.D. the political and environmental conjuncture changed the social constitution of the valley as the agrarian landscape was segregated from household areas and a new spatial logic was recognized in the archaeological record (Franco Salvi \& Molar 2018).

Lithic assemblages analyzed were recovered from two dwellings and a temporary use enclosure. The two dwellings - Unit 10 (U10) and Unit 14 (U14) - are located in LB1 while the temporary use enclosure -Shelter- is located in LB2 (Figures 3 and 4).

In case of dwellings (Figure 3) they include a circular open courtyard, about 10-20 m wide, surrounded by circular rooms ranging from 2 to $8 \mathrm{~m}$ wide, both built with large stone masonry (Berberián \& Nielsen 1988; Franco Salvi 2012; Salazar 2010) and inhabited during the $3^{\text {rd }}$ to $8^{\text {th }}$ centuries CE. These clusters vary in size and number of structures attached to the central patio courtyard (from 3 to 15, with 5 in average), but in all cases with the same spatial organization around circular rooms connected to a large "patio". Excavations indicate that the burial cists were often located in the center of these patios. Domestic groups with extensive and highly competitive segmental identities were responsible for building these large houses (Salazar 2010; Salazar et al. 2007).

The temporary use enclosure is attached to a rectangular enclosure (Figure 4) corresponding to the second millennium of the CE (Franco Salvi \& Molar 2018). The recovered materiality (i.e., black on white Santamaria pottery sherds, and architecture typology) and the archaeobotanical analysis (micro remains of maize) suggests that the structure was a crop field with a seasonal position control of agricultural activities. Obsidian artifacts come from a layer with remains that, according to the absolute and relative dates, correspond to the $13^{\text {th }}$ century CE, a particular period in the Northwest of Argentina due to the prevailing drought and potential conflicts (Nielsen 2006a). 


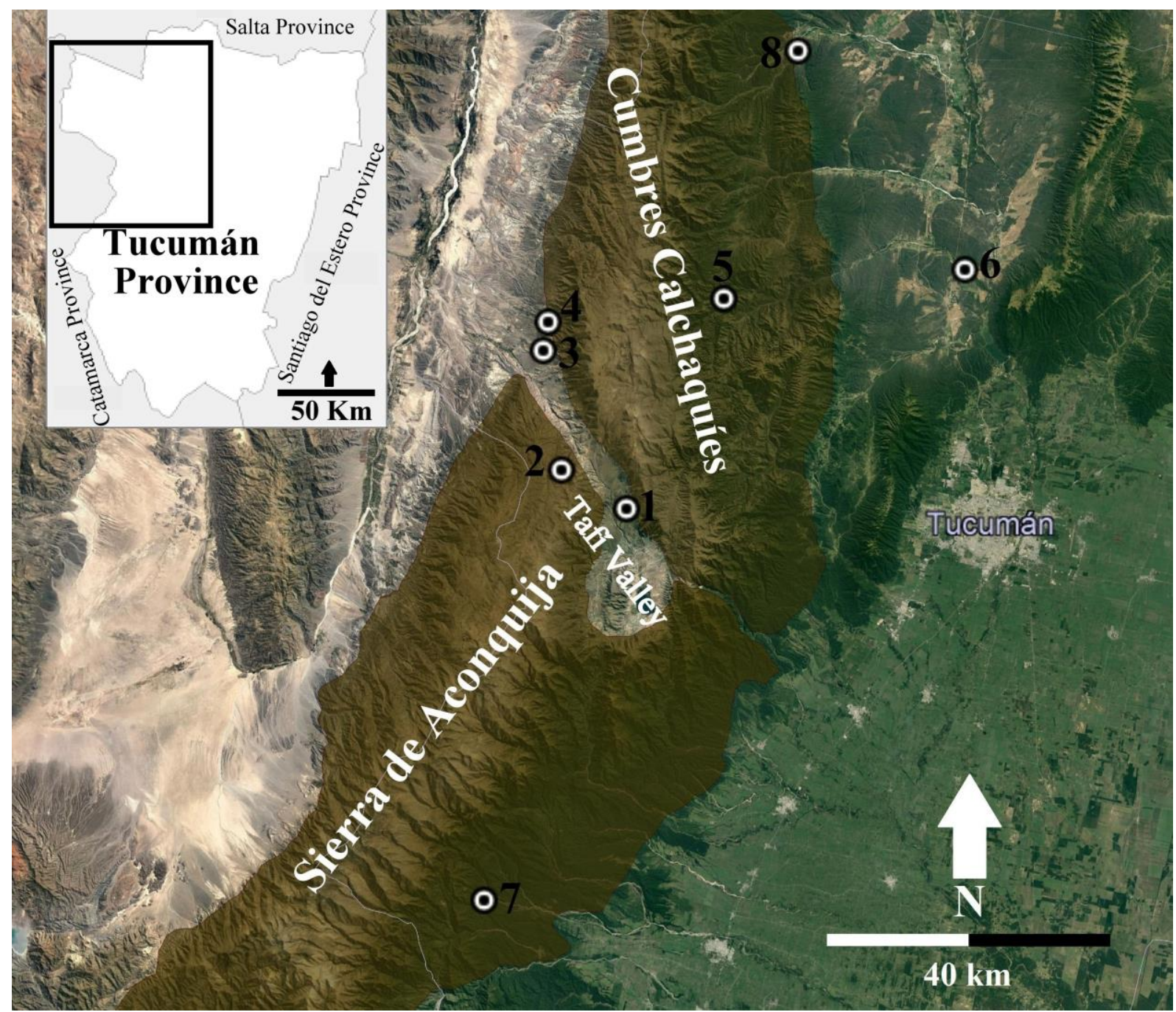

Figure 2. Location of the Tafí Valley (northwest of the Tucumán province) and archaeological sites mentioned in the text (1. La Bolsa 1 and 2; 2. Puesto Viejo 1; 3. El Observatorio; 4. El Divisadero; 5. Terraza; 6. Ticucho 1; 7. Santa Rosa; 8. Tambo).

\section{Methods}

Obsidian artifacts were subjected to two types of studies. On the one hand, technomorphological and morphological-functional analyses according to Aschero $(1975 ; 1983)$ and Sullivan and Rosen (1985) proposals adapted to the case study were applied. Thus, the percentage ratio between obsidian and other lithic resources was considered and compared to quantify the consumption of this raw material. Then, the obsidian set was divided and analyzed into typological categories of debitage, cores and instruments. Origin of the extraction, type of platform and the relative size of the chips were recorded. In the cores, morphological designation and the presence or absence of cortex was important. Finally, in the typological groups of instruments, technical series and the stage of the flaking sequence were characterized. These data were analyzed to determine the use of the lithic resource. 


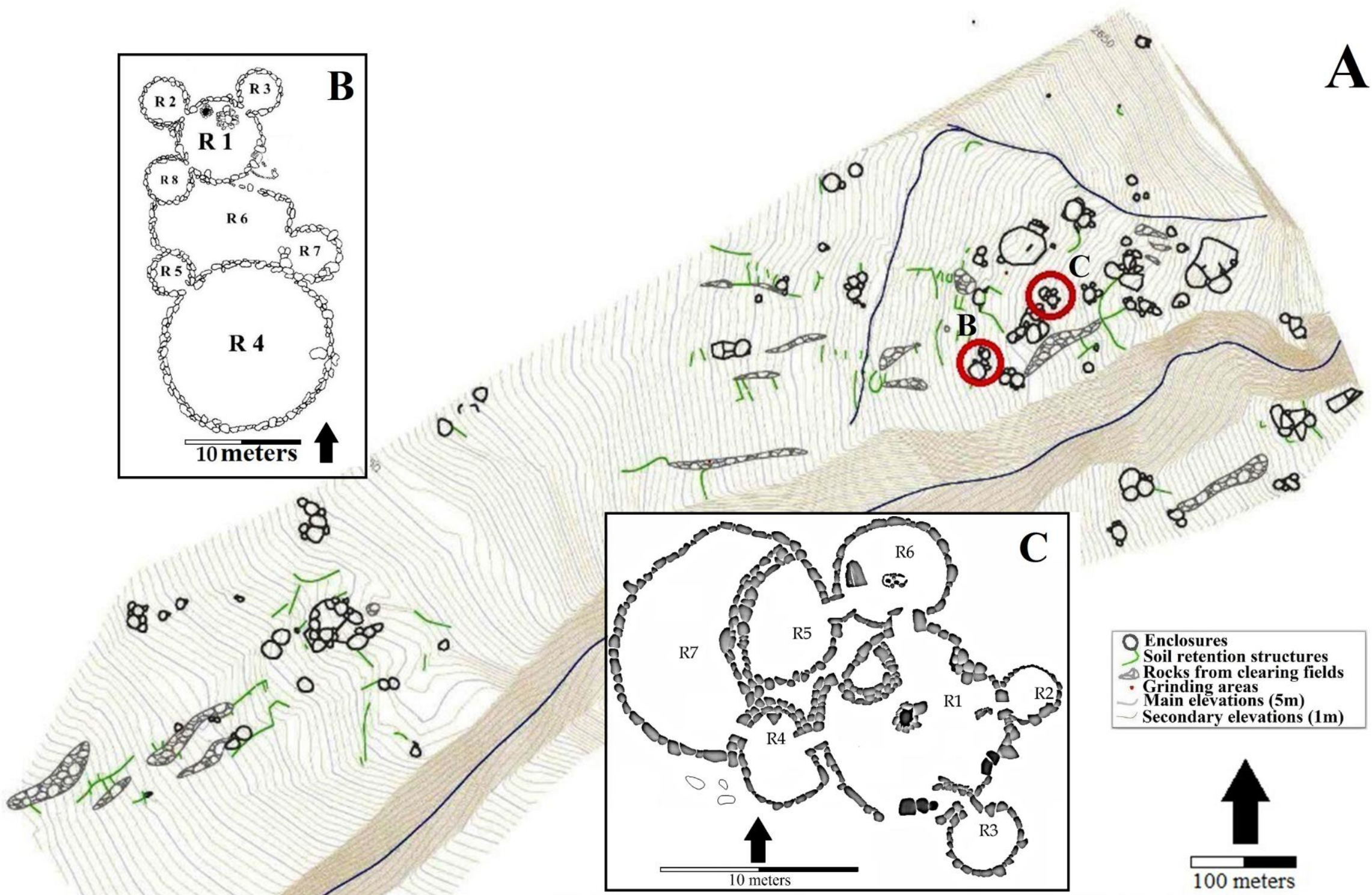

Figure 3. Archaeological site of La Bolsa 1 (A) and structures from which the lithic groups came (B. Unit U10; C. Unit U14). 


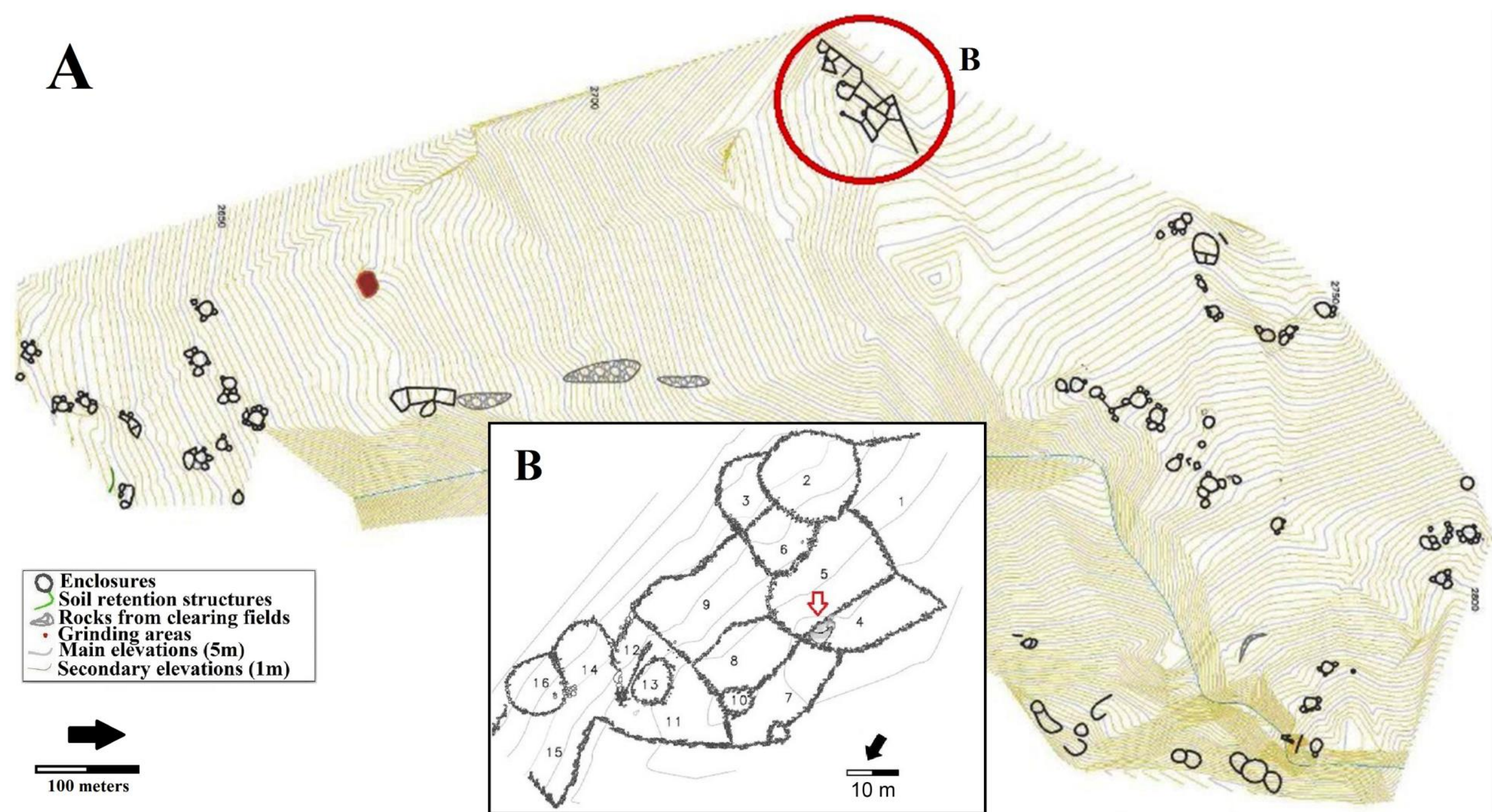

Figure 4. Archaeological site of La Bolsa 2 (A) and structure from which the lithic groups came (B. rectangular enclosure attached to a shelter). 
On the other hand, a sample was selected for geochemical analysis using x-ray fluorescence (ED-XRF). Samples were sent to the Archaeometry Laboratory of the Research Reactor Center at the University of Missouri (MURR) and compared to Northwest Argentina obsidian for facilitating identification. The samples were selected based on stratigraphic layers (when appropriate) and macroscopic characteristics, such as color, brightness, transparency, inclusions, etc. These selection parameters were applied in order to distinguish multiple uses according to historical processes and possible sources of supply. It should be noted that the obsidian assemblages have highly uniform macroscopic characteristics, so those which had some particular external characteristic were selected. All XRF measurements were performed using a ThermoScientific ARL QuantX energy-dispersive XRF spectrometer. The instrument has a rhodium-based x-ray tube and thermoelectrically-cooled silicon-drift detector (SDD). The tube was operated at $35 \mathrm{kV}$, with a $3.5 \mathrm{~mm}$ collimator, and the current was automatically adjusted to create a deadtime of approximately $25 \%$. The samples were counted for two minutes each allowing measurement of nine elements: $\mathrm{Mn}, \mathrm{Fe}, \mathrm{Zn}, \mathrm{Rb}, \mathrm{Sr}, \mathrm{Y}$, $\mathrm{Zr}, \mathrm{Nb}$, and $\mathrm{Th}$.

\section{Data results}

Techno-morphological and morphological-functional studies of the flaked obsidian corresponding to the two archaeological sites showed, firstly, that obsidian is a very rare resource, not exceeding in any case $2 \%$ of the lithic assemblage (Table 1 ). On the other hand, the predominant typological classes correspond to debitage and instruments (Table 1), with only a small core in LB1-U14 that shows signs of reduction by bipolar technique and absence of cortex (Figure 5).
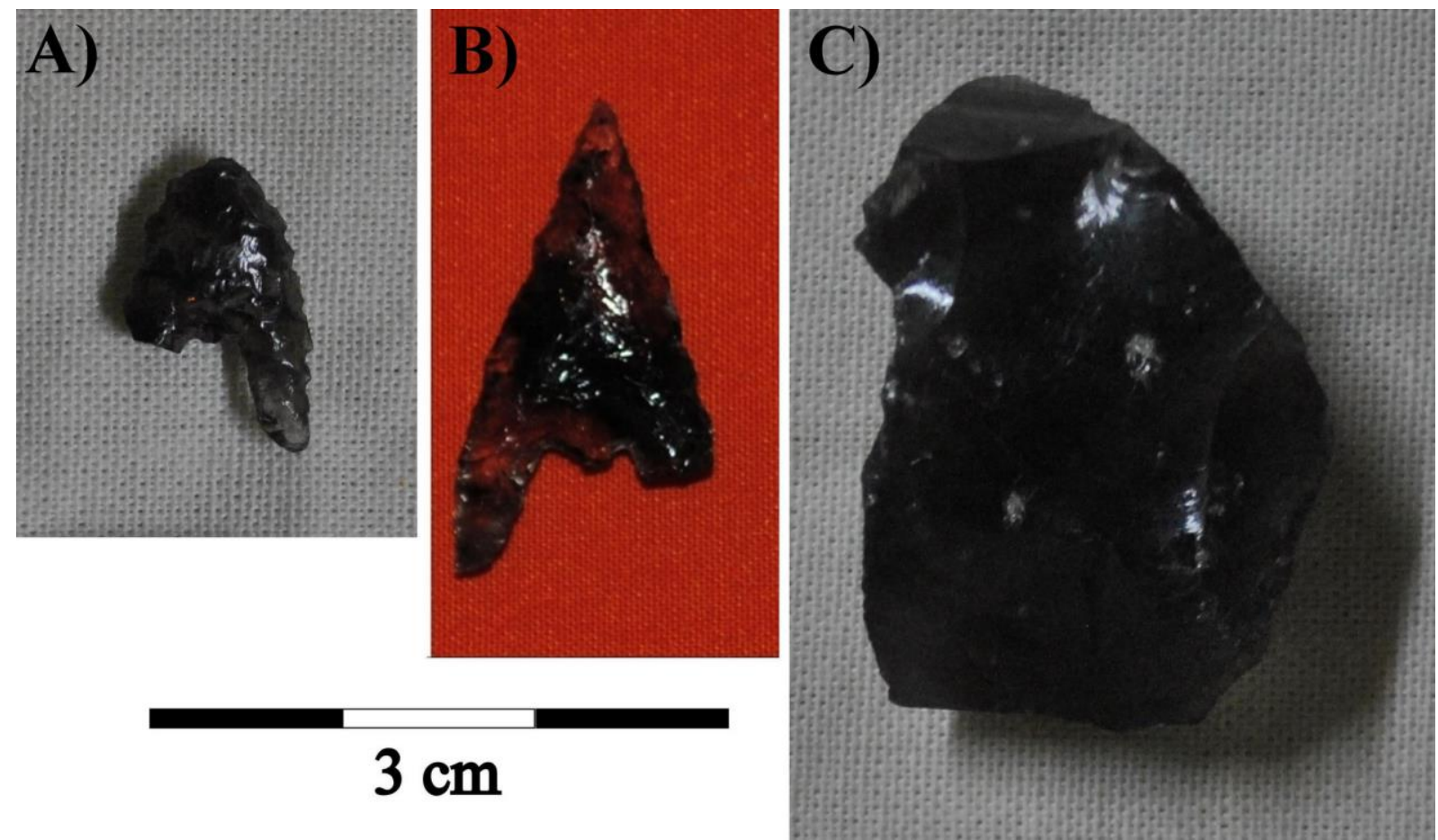

Figure 5. Obsidian artifacts from the analyzed sets. A and B. small stemmed triangular projectile point with bifacial flaking; C. small core with signs of bipolar technique and absence of cortex. 
Table 1. Typological categories of artifacts and composition lithic assemblages according raw materials and contexts.

\begin{tabular}{llcccccccc}
\hline & & \multicolumn{2}{c}{ Debitage } & \multicolumn{2}{c}{ Cores } & \multicolumn{2}{c}{ Instruments } & \multicolumn{2}{c}{ Total } \\
Context & Raw Material & $\mathbf{N}$ & $\mathbf{\%}$ & $\mathbf{N}$ & $\mathbf{\%}$ & $\mathbf{N}$ & $\mathbf{\%}$ & $\mathbf{N}$ & $\mathbf{\%}$ \\
\hline LB1-U14 & quartz & 868 & $97.9 \%$ & 7 & $0.8 \%$ & 12 & $1.4 \%$ & 887 & $67.5 \%$ \\
& andesite & 179 & $97.3 \%$ & & & 5 & $2.7 \%$ & 184 & $14 \%$ \\
& quartzite & 124 & $100 \%$ & & & & & 124 & $9.4 \%$ \\
& obsidian & 11 & $73.3 \%$ & 1 & $6.7 \%$ & 3 & $20 \%$ & 15 & $1.1 \%$ \\
& chalcedony & 3 & $100 \%$ & & & & & 3 & $0.2 \%$ \\
& slate & 37 & $94.9 \%$ & & & 2 & $5.1 \%$ & 39 & $3 \%$ \\
& metamorphic & 30 & $100 \%$ & & & & & 30 & $2.3 \%$ \\
& undetermined & 32 & $100 \%$ & & & & & 32 & $2.4 \%$ \\
& Total & $\mathbf{1 2 8 4}$ & $\mathbf{9 7 . 7 \%}$ & $\mathbf{8}$ & $\mathbf{0 . 6 \%}$ & $\mathbf{2 2}$ & $\mathbf{1 . 7 \%}$ & $\mathbf{1 3 1 4}$ & $\mathbf{1 0 0 \%}$ \\
\hline LB1-U10 & quartz & 300 & $94.3 \%$ & 10 & $3.1 \%$ & 8 & $2.5 \%$ & 318 & $49.7 \%$ \\
& andesite & 225 & $98.3 \%$ & & & 4 & $1.7 \%$ & 229 & $35.8 \%$ \\
& quartzite & 10 & $76.9 \%$ & & & 3 & $23.1 \%$ & 13 & $2 \%$ \\
& obsidian & 2 & $50 \%$ & & & 2 & $50 \%$ & 4 & $0.6 \%$ \\
& chalcedony & 1 & $100 \%$ & & & & & 1 & $0.2 \%$ \\
& undetermined & $\mathbf{7 4}$ & $98.7 \%$ & & & 1 & $1.3 \%$ & 75 & $11.7 \%$ \\
& Total & $\mathbf{6 1 2}$ & $\mathbf{9 5 . 6 \%}$ & $\mathbf{1 0}$ & $\mathbf{1 . 6 \%}$ & $\mathbf{1 8}$ & $\mathbf{2 . 8 \%}$ & $\mathbf{6 4 0}$ & $\mathbf{1 0 0 \%}$ \\
\hline LB2-Shelter & quartz & $\mathbf{2 2 1}$ & $98.7 \%$ & & & 3 & $1.3 \%$ & 224 & $97.8 \%$ \\
& andesite & 2 & $100 \%$ & & & & & 2 & $0.9 \%$ \\
& quartzite & 1 & $100 \%$ & & & & 1 & $0.4 \%$ \\
& obsidian & 1 & $50 \%$ & & & 1 & $50 \%$ & 2 & $0.9 \%$ \\
& Total & $\mathbf{2 2 5}$ & $\mathbf{9 8 . 3 \%}$ & $\mathbf{0}$ & & $\mathbf{4}$ & $\mathbf{1 . 7 \%}$ & $\mathbf{2 2 9}$ & $\mathbf{1 0 0 \%}$ \\
\hline
\end{tabular}

As for the typological groups of the instruments, three small or very small stemmed and unstemmed triangular projectile points were recorded (Table 2 and Figure 5). All of them have bifacial flaking and, in some cases, traces of reactivation. A burin point and two flaking edges were also recorded (Table 2). These last three instruments, recovered in dwellings, had been related to food processing (Franco Salvi et al. 2016; Salazar et al. 2007).

Finally, debitage is dominated by flakes generated in advanced production tasks (i.e., internal, formatization flakes), with prepared platforms (mainly punctiform), whose sizes are small (Table 3).

XRF analyses were conducted on four obsidian samples: one sample comes from U10, while the other two samples from U14 and the last one from the shelter. Table 4 and Figure 6 shows the trace elements analyzed by ED-XRF and their values as well as the macroscopic characteristics of the samples.

In Figure 7 and 8 bivariate graphs used to establish the relationship with the sources recorded in the MURR show that all the samples in question came from the Ona-Las Cuevas source, located at a linear distance by approximately $240 \mathrm{~km}$ from the sites (Figure 1).

It should be noted that the other obsidian artifacts analyzed so far have the same macroscopic characteristics as the samples chemically analyzed, therefore it is understood that they come from the same identified source. 
Table 2. Typological groups of instruments according raw material and contexts. References: Qz - quartz; And andesite; Ob - obsidian; Sl - slate; Qzite - quartzite; Undet - undetermined; NECF - Natural edge with complementary features; SFA - Simple flaking artifact; UFFA - Undifferentiated fragment of flaking artifact.

\begin{tabular}{|c|c|c|c|c|c|c|c|c|c|c|c|c|}
\hline \multirow{2}{*}{$\begin{array}{l}\text { Context } \\
\text { Raw Material }\end{array}$} & \multicolumn{4}{|c|}{ LB1-U14 } & \multicolumn{5}{|c|}{ LB1-U10 } & \multicolumn{2}{|c|}{ LB2-Shelter } & \multirow[b]{2}{*}{ Total } \\
\hline & Qz & And & Ob & SI & Qz & And & Qzite & Ob & Undet & Qz & $\mathrm{Ob}$ & \\
\hline Projectile point & 4 & & 2 & & 1 & & 1 & & & 1 & 1 & 10 \\
\hline Burin point & & 1 & 1 & & & & & & & & & 2 \\
\hline Notch + flaking edge & 1 & & & & & & & & & & & 1 \\
\hline Notch & & 1 & & & 2 & & & & & 1 & & 4 \\
\hline Scraper & 1 & & & & 1 & & & & & & & 2 \\
\hline Raedera & & & & & & 1 & & & & & & 1 \\
\hline NECF & 1 & & & & & & & & & 1 & & 2 \\
\hline Flaking edge & & 1 & & 1 & 2 & 3 & 1 & 2 & & & & 10 \\
\hline Hammerstone & 2 & & & & & & & & & & & 2 \\
\hline SFA & 1 & 1 & & & 2 & & 1 & & 1 & & & 6 \\
\hline UFFA & 2 & 1 & & 1 & & & & & & & & 4 \\
\hline Total & 12 & 5 & 3 & 2 & 8 & 4 & 3 & 2 & 1 & 3 & 1 & 44 \\
\hline
\end{tabular}

Table 3. Debitage data. References: IF - internal flake; EF - external flake; FF - formatization flake; C - cortical; Sm - smooth; D - dihedral; F - faceted; P - punctiform; VS - very small; S - small; MS - medium small; ML medium large; L - large; VL - very large.

\begin{tabular}{|c|c|c|c|c|c|c|c|c|c|c|}
\hline \multirow{2}{*}{$\begin{array}{r}\text { Contex } \\
\text { Raw materia }\end{array}$} & & \multicolumn{3}{|c|}{ LB1-U14 } & \multicolumn{3}{|c|}{ LB1-U10 } & \multicolumn{3}{|c|}{ LB2-Shelter } \\
\hline & & Other & Obsidian & Total & Other & Obsidian & Total & Other & Obsidian & Tota \\
\hline \multirow{3}{*}{$\begin{array}{l}\text { Origin of } \\
\text { extraction }\end{array}$} & IF & 582 & 10 & 592 & 240 & 2 & 242 & 82 & & 82 \\
\hline & $\mathrm{EF}$ & 153 & & 153 & 63 & & 63 & 14 & 1 & 15 \\
\hline & $\mathrm{FF}$ & 29 & 1 & 30 & 12 & & 12 & 6 & & 6 \\
\hline \multirow[t]{5}{*}{ Platform } & $\mathrm{C}$ & 36 & & 36 & 15 & & 15 & 9 & & 9 \\
\hline & Sm & 172 & 2 & 174 & 71 & & 71 & 48 & & 48 \\
\hline & $\mathrm{D}$ & 12 & 1 & 13 & 6 & & 6 & & 1 & 1 \\
\hline & $F$ & 20 & 1 & 21 & 9 & 1 & 10 & & & 0 \\
\hline & $P$ & 15 & 7 & 22 & 4 & 1 & 5 & 5 & & 5 \\
\hline \multirow[t]{6}{*}{ Size } & VS & 16 & 1 & 17 & 11 & 2 & 13 & 9 & & 9 \\
\hline & $S$ & 32 & 10 & 42 & 14 & & 14 & 27 & 1 & 28 \\
\hline & MS & 10 & & 10 & 4 & & 4 & & & 0 \\
\hline & $\mathrm{ML}$ & 15 & & 15 & 1 & & 1 & & & 0 \\
\hline & $\mathrm{L}$ & 3 & & 3 & 1 & & 1 & & & 0 \\
\hline & VL & 1 & & 1 & & & 0 & & & 0 \\
\hline
\end{tabular}

Table 4. Concentrations of elements in parts per million measured in obsidian artifacts from Tafí Valley by EDXRF.

\begin{tabular}{lllllllllllll}
\hline Site & Context & ID Sample & Description & Mn & Fe & Zn & $\mathbf{R b}$ & Sr & Y & Zr & Nb & Th \\
\hline LB1 & Unit 10 & JM001 & Light grey, translucent & 454 & 5269 & 27 & 233 & 137 & 15 & 81 & 20 & 25 \\
LB1 & Unit 14 & JM002 & Light grey, translucent & 460 & 5258 & 27 & 238 & 140 & 16 & 89 & 18 & 27 \\
LB1 & Unit 14 & JM003 & Dark grey, translucent & 456 & 5104 & 27 & 237 & 138 & 17 & 79 & 19 & 26 \\
LB2 & Shelter & JM004 & Light grey, translucent & 454 & 5547 & 32 & 232 & 139 & 16 & 82 & 19 & 26 \\
\hline
\end{tabular}



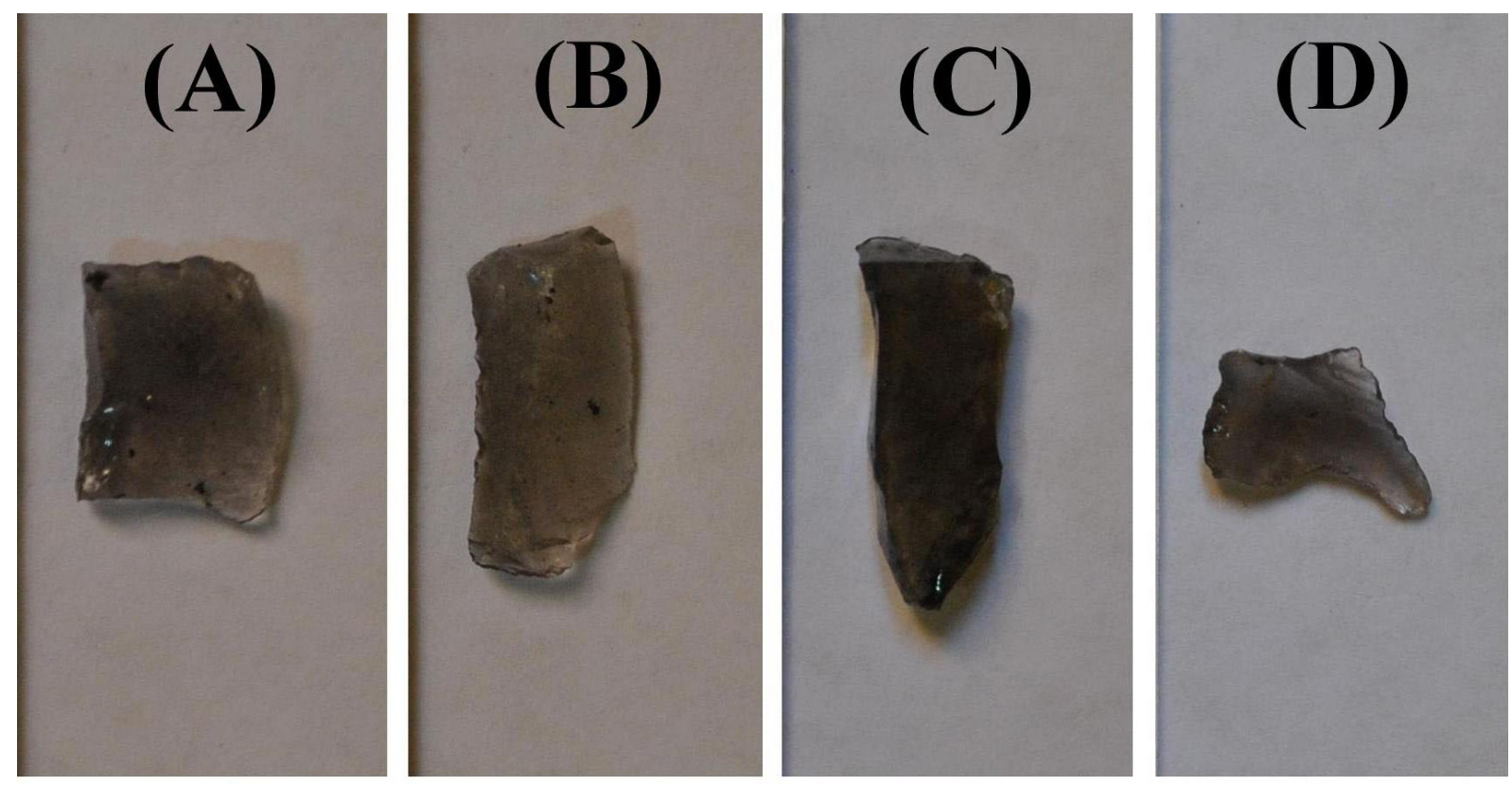

\section{$3 \mathbf{c m}$}

Figure 6. Obsidian samples from Tafí Valley analyzed by ED-XRF. A. JM001 flake from LB1-U10; B and C. JM002 and JM003 flakes from LB1-U14; D. JM004 base of projectile point fractured from LB2-Shelter.

\section{Data interpretation}

The presence of obsidian, as a foreign resource whose source is located at a great distance $(240 \mathrm{~km})$, shows that the pre-Hispanic inhabitants of Tafí valley turned to special practices for the procurement of this raw material. This evidence suggests long distance relationships with people living in Puna highlands or their intermediaries, through practices that could include exchange, alliances, cooperation, or caravan systems.

The use of the same source from around 200 BCE to 1400 CE shows stability in the OnaLas Cuevas long distance network of obsidian circulation (Escola 2007). That is to say, those relationships were maintained despite social, political and economic changes in this long period. In a micro-regional scale, provenance studies carried out in neighboring areas showed the same pattern. Caria et al. (2009) characterized obsidian sources from a large sample taken from archaeological sites dated to the First and Second Millennium of CE in the eastern (Terraza, Tambo, and Ticucho 1) and western (El Divisadero, El Observatorio, and Puesto Viejo 1) slopes of the Cumbres Calchaquíes ranges (Figure 2). The obsidian came mainly from Ona-Las Cuevas, and in an insignificant proportion from Laguna Cavi and Cueros de Purulla. Míguez et al. (2015) identified also Ona-Las Cuevas obsidian in the first millennium CE archaeological site of Santa Rosa, in the eastern slopes of Sierras del Aconquija (Figure 2). Therefore, Tafi valley was involved in the circulation sphere of this source whose range of action was broader than other sources' spheres in the southern Puna.

In relation to the presence of a single source, other sources of obsidian have been recorded that provided materials to different archaeological sites (Caria et al. 2009; Escola 2007). In turn, some sources are located closer to Tafi Valley, such as Laguna Cavi and Cueros de Purulla located 160 and $170 \mathrm{~km}$ away respectively. Although it is possible that these sources were used, it is noteworthy that they did not present a geographical dispersion or a temporary stability in their use, as in the case of Ona-Las Cuevas (Escola 2007; Yacobaccio et al. 2004). On the other hand, these sources do not have the same aesthetic characteristics as Ona-Las Cuevas. Laguna Cavi obsidian for example is dark gray not fully 
translucent (Escola et al. 2007). Finally, the presence of important human settlements during the pre-Hispanic period around Ona-Las Cuevas - i.e., Antofagasta de Sierra (Escola 2000), Salar de Antofalla (Moreno 2005) - could have allowed the establishment of long-distance relationships. Therefore, a specific combination of natural, aesthetic and social factors could have influenced the use of Ona-Las Cuevas over other sources.

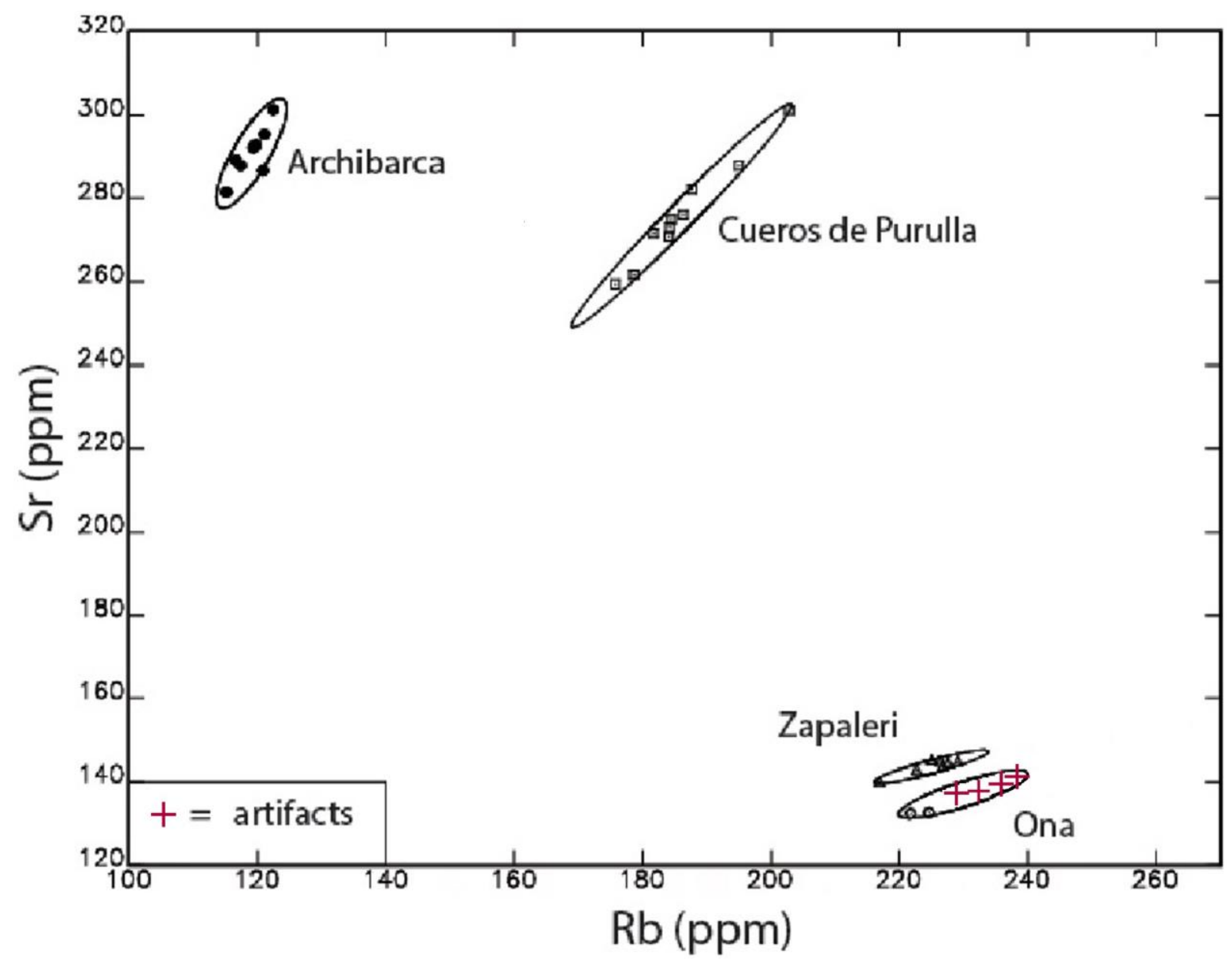

Figure 7. Scatterplot of Rubidium versus Strontium measured by ED-XRF. Artifacts (+) have been projected against $90 \%$ confidence ellipses.

Regarding the use of obsidian in the study area, the scarce presence of cores and the appearance of knapping debitage coming either from final formatization, or recycling tasks, would state that most of this raw material entered to the sites either as almost-prepared base forms for their final manufacture, or as final products. It is possible that the material was obtained through the exchange of transportable size obsidian pieces and or by direct access (Meltzer 1989) to the source. It should be noticed that archaeological research carried out by Escola (2000) in the Ona-Las Cuevas source evidenced core selection, testing and crust extraction activities, as well as flake extraction for carrying, and use in far locations. Therefore, this lithic resource played a key role, together with other resources, in an intense traffic network that lasted at least from 2200 to 400 BP (Lazzari 1997; Nielsen 2006b).

On a smaller scale, the presence of obsidian tools in household settings or in contexts of embedded activities (Binford 1979) of Tafí Valley shows that procurement, use, and disposal of this "exotic" good was managed by and within daily, and possibly kinship relationships. Furthermore, the use of this raw material for projectile points, edges and point tool evidences that obsidian would have been directly related to subsistence and feeding practices, such as 
hunting and food processing. Due to the fact that so far no evidences of conflict situations were found -as it happens in neighboring sectors for the second millennium of the $\mathrm{CE}$ (Carbonelli 2014; Martínez et al. 2010)-, it is not possible to determine if projectile points were used in social conflicts within Tafi Valley.

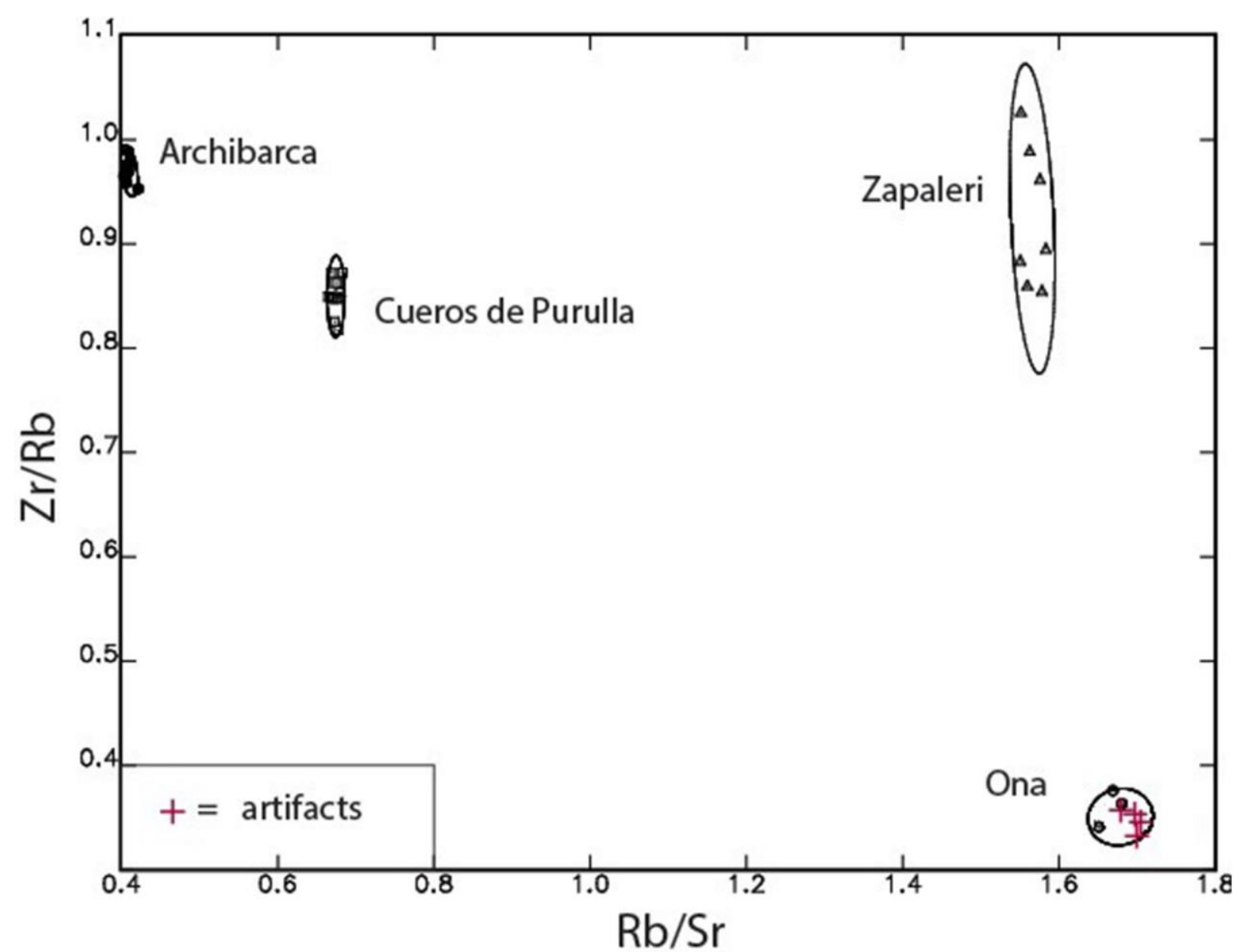

Figure 8. Scatterplot of ratios of Rubidium and Strontium versus Zirconium and Strontium measured by EDXRF. Artifacts (+) have been projected against $90 \%$ confidence ellipses.

It is worth noting that in the study area and surroundings, such as Quebrada de los Corrales and Amaicha, there is a good availability of knapping materials (i.e., andesite, quartz) and in fact projectile points in these materials were recorded (Franco Salvi et al. 2016; Mercuri \& Mauri 2015; Salazar 2006; Somonte 2009). Therefore, the use of obsidian in confrontation to this scene is striking. It is possible, as mentioned by Escola (2007), that beyond the physical-mechanical properties that make obsidian ideal for the knapping of projectile points, social factors had to influence this relationship between raw material and instrumental typology. This author emphasizes the central role of the obsidian within interaction networks as a potential container of coded information that was transmitted from group to group, within which the manufacturing of projectile points must have connoted a very specific knowledge (Escola 2007). In turn, for Moreno (2005), the aesthetic aspects of obsidian (i.e., brightness, transparency) should have been significant properties in its collection and use, while its ductile knapping properties made it a relevant resource in the transmission of knowledge through learning practices in the production of points, which would have occurred from generation to generation and from masters to trainees.

The presence of a resource that requires effort to obtain it and that is strongly related to the macroregional circulation and with specific instruments forms may be marking a 
particular role of obsidian over other raw materials more abundant in lithic assemblages. In our cases, for example, quartz represents $50 \%$ or more of the assemblages and it has brightness natural qualities. However, quartz is not mediated by distance and interaction with other groups because it is an immediate local resource (Franco Salvi et al. 2016; Salazar et al. 2007).

These proposals require further study, but they open up the possibility to go beyond the utilitarian value of obsidian, obtaining new hypotheses about its circulation and consumption in order to progress in the study of the relationships between people and objects.

\section{Conclusions}

The analyses and discussion of this study allowed to identify the source of the obsidian artifacts recovered and to learn about the way in which obsidian was consumed in the study area. Evidence suggests that obsidian was a resource primarily involved in long-distance relationships and subsistence practices which were vital to the social and biological reproduction of pre-Hispanic people. Relations with other social groups to obtain information and or resources, as well as obtaining and processing food would have been practices developed routinely by household groups. The use of obsidian within these areas could have granted to this raw material an outstanding role in the daily life of the pre-Hispanic inhabitants of the Tafi Valley during the first and second millennium of the CE.

On the other hand, it was possible to start thinking about other types of roles -e.g., information carrier, information transmitter, long-distance linkage mechanism- that obsidian possibly played in Northwest Argentina.

It should be noted that in the area of study and at a regional level, the provenance and technological studies on this type of resource should be expanded in order to further analyze the ideas expressed in this project work.

\section{Acknowledgments}

We wish to acknowledge the kind and warm treatment we receive from Tafí Diaguita Communities, without which this project would have been impossible. This study was enriched by the assistance of E. E. Berberián, R. M. Molar, S. Chiavassa Arias, G. Moyano, F. Franco, A. Vazquez Fiorani and D. Carrasco. We would like to acknowledge Dr. Michael Glascock and the Archaeometry Laboratory at MURR for carried out the geochemical analysis. A special thanks to the organizers of the 11th International Symposium on Knappable Materials and to Dr. Otis Crandell for their collaboration in the editing process of the article. Finally, we thank the reviewers whose contributions have improved this research. This research has been supported by SECyT (Secretaría de Ciencia y Técnica, Universidad Nacional de Córdoba), CONICET (Consejo Nacional de Investigaciones Científicas y Técnicas), Koeki Zaidan Hojin Toyota Zaidan (公益財団法人トヨタ財団), The Toyota Foundation under Grant TYTID: D16-R-0718, National Geographic Society under Grant W464-16, and Centro de Estudios Históricos 'Prof. C.S.A. Segreti'.

\section{References}

Aschero, C. (1975). Ensayo para una clasificación morfológica de los artefactos líticos aplicada a estudios tipológicos comparativos.Unpublished manuscript, Buenos Aires. 85 p. (in Spanish) ("Essay for a morphological classification of lithic artifacts applied to comparative typological studies") 
Aschero, C. (1983). Ensayo para una clasificación morfológica de artefactos líticos aplicada a estudios tipológicos comparativos. Apéndices A-C. Revisión.Unpublished manuscript, Buenos Aires. 20 p. (in Spanish) ("Test for a morphological classification of lithic artifacts applied to comparative typological studies. Appendices A-C. Review”)

Berberián, E.E. \& Nielsen, A.E. 1988, Sistemas de asentamiento prehispánicos en el valle de Tafí. Editorial Comechingonia, Córdoba, 178 p. (in Spanish) ("Prehispanic settlement systems in the Tafi Valley")

Binford, L.R. 1979, Organization and formation processes: Looking at curated technologies. Journal of Anthropological Research, 35(3): 255-273. doi:10.1086/jar.35.3.3629902

Carbonelli, J. 2014, Obsidianas y puntas de proyectil: Sustancia y forma de las relaciones sociales en Las Pailas, Catamarca, Argentina. Revista Colombiana de Antropología, 50: 117-137. (in Spanish) ("Obsidian and Projectile Points: Substance and Form of Social Relations in Las Pailas, Catamarca, Argentina”) doi:10.22380/2539472x59

Caria, M., Escola, P., Gómez Augier, J.P. \& Glascock, M. 2009, Obsidian circulation: New distribution zones for the Argentinean northwest. International Association Obsidian Studies Bulletin, 40: 5-11. URL: https://www.academia.edu/11294911/

Chaparro, M.G. 2009, El manejo de los recursos líticos en el pasado. Sociedades preestatales y estatales en el área Valliserrana del noroeste argentino (1000-1536 DC) at the Facultad de Filosofía y Letras, Universidad de Buenos Aires, Buenos Aires, 589 p. (in Spanish) ("The management of lithic resources in the past. Pre-state and state companies in the Valliserrana area of the Argentine northwest (1000-1536 CE)") URL: http://repositorio.filo.uba.ar/handle/filodigital/1859

Escola, P. 2000, Tecnología lítica y sociedades agro-pastoriles tempranas at the Facultad de Filosofía y Letras, University of Buenos Aires, Buenos Aires, 326 p. (in Spanish) ("Lithic technology and early agro-pastoral societies")

Escola, P. 2004, Variabilidad en la explotación y distribución de obsidianas en la Puna Meridional argentina. Estudios Atacameños, 28: 9-24. (in Spanish) ("Variability in the exploitation and distribution of obsidians in the southern Puna of Argentina")

Escola, P. 2007, Obsidianas en contexto: Tráfico de bienes, lazos sociales y algo más. In: Sociedades precolombinas surandinas. Temporalidad, interacción y dinámica cultural en el NOA en el ámbito de los Andes Centro-Sur (Ventura, B., Callegari, A. \& Yacobaccio, H., Eds.), Buschi Ed., Buenos Aires: p. 73-87. (in Spanish) (“'Obsidian in context: goods traffic, social ties and something more") URL: https://www.academia.edu/7266411

Escola, P., Glascock, M.D., Korstanje, M.A. \& Sentinelli, N. 2007, Laguna Cavi y El Médano: Obsidianas en circulación caravanera. In: Arqueometría Latinoamericana: Segundo Congreso Argentino y Primero Latinoamericano Vol. 1 (Palacios, O., Vásquez, C., Palacios, T. \& Cabanillas, E., Eds.), Comisión Nacional de Energía Atómica (CNEA), Buenos Aires: p. 103-108. (in Spanish) ("Laguna Cavi and El Médano: Obsidian in caravan circulation”)

Escola, P. \& Hocsman, S. 2007, Procedencia de artefactos de obsidiana de contextos arqueológicos de Antofagasta de la Sierra (ca. 4500-3500 AP). Comechingonia. Revista de Arqueología, 10: 49-61. (in Spanish) ("Origin of obsidian artifacts from archaeological contexts of Antofagasta de la Sierra (ca. 4500-3500 BP)") URL: https://www.researchgate.net/publication/303637337 
De Feo, M.E. \& Álvarez Soncini, M.C. 2010, Estudio tecno-morfológico y análisis de procedencia de obsidianas recuperadas en el sitio formativo Tres Cruces I (Quebrada del Toro, provincia de Salta, Argentina). In: La Arqueometría en Argentina y Latinoamérica (Bertolino, S., Cattáneo, R. \& Izeta, A.D., Eds.), Facultad de Filosofía y Humanidades, Universidad Nacional de Córdoba, Córdoba: p. 165-170. (in Spanish) ("Techno-morphological study and analysis of provenance of obsidian recovered in the Tres Cruces I formative site (Quebrada del Toro, Salta Province, Argentina)") URL: https://www.academia.edu/2532073

Franco Salvi, V. 2012, Estructuración social y producción agrícola prehispánica durante el primer milenio D.C. en el Valle del Tafí (Tucumán, Argentina) at the Facultad de Filosofía y Humanidades, Universidad Nacional de Córdoba, Córdoba, 374 p. (in Spanish) ("Social structuring and pre-Hispanic agricultural production during the first millennium CE in the Tafi Valley (Tucumán, Argentina)")

Franco Salvi, V. \& Molar, R.M. 2018, Paisajes agrarios del segundo milenio de la Era en el sector norte del Valle de Tafí (Tucumán, Argentina). Estudios Atacameños, 57: 45-63. (in Spanish) ("Agrarian landscape of the second millennium CE in the Northern area of Tafí Valley (Tucumán, Argentine)”) doi:10.4067/s0718-10432018005000602

Franco Salvi, V., Salazar, J. \& J., M. 2016, Prácticas cotidianas y vida aldeana. Un análisis desde la tecnología lítica en el Valle de Tafí (Tucumán, Argentina). Cuadernos del Instituto Nacional de Antropología y Pensamiento Latinoamericano, 25: 141-158. (in Spanish) ("Daily practices and village life. An analysis from the lithic technology in the Tafi Valley (Tucumán, Argentine)")

URL: http://revistas.inapl.gob.ar/index.php/cuadernos/article/view/947

Gáal, E. 2014, Decisiones Tecnológicas y Producción Lítica en el Sur del Valle de Yocavil (Pcia. de Catamarca). Un Estudio Comparativo de Conjuntos Artefactuales Tempranos y Tardios at the Facultad de Filosofía y Letras, Universidad de Buenos Aires, Buenos Aires, 304 p. (in Spanish) ("Technological Decisions and Lithic Production in the South of the Valley of Yocavil (Province of Catamarca). A Comparative Study of Early and Late Artifactual Sets")

Hermo, D. 2008, Rocas como símbolos: La selección de materias primas para puntas de proyectil en ambientes mesetarios de Patagonia. Intersecciones en Antropología, 9: 319324. (in Spanish) ("Rocks as symbols: the selection of raw material for projectile points in Patagonian plateau environments")

URL: http://www.ridaa.unicen.edu.ar/xmlui/handle/123456789/1060

Hocsman, S. 2006, Tecnología lítica en la transición de cazadores recolectores a sociedades agropastoriles en porción meridional de los Andes Centro Sur. Estudios Atacameños, 32: 59-73. (in Spanish) ("Lithic technology in the transition from hunter-gatherers to agro-pastoral societies in the southern portion of the Southern Central Andes") doi:10.4067/s0718-10432006000200006

Lazzari, M. 1997, La economía más allá de la subsistencia: intercambio y producción lítica en Aconquija. Arqueología , 7: 9-50. (in Spanish) ("The economy beyond subsistence: exchange and lithic production in Aconquija") 
Martínez, J., Caria, M., Mauri, E. \& C., M. 2010, Puntas de proyectil líticas de colección. Aportes para la Arqueología de tierras bajas (Cuenca Tapia-Trancas, Tucumán, Argentina). In: La arqueometría en Argentina y Latinoamérica (Bertolino, S., Cattáneo, R. \& Izeta, A., Eds.), Facultad de Filosofía y Humanidades, Universidad Nacional de Córdoba, Córdoba: p. 189-196. (in Spanish) ("Lithic projectile points collection. Contributions for the lowland archeology (Tapia-Trancas Basin, Tucumán, Argentina)") URL: https://www.researchgate.net/publication/262336636

Meltzer, D.J. 1989, Was stone exchanged among eastern north american paleoindians? In: Eastern Paleoindian lithic resource use (Ellis, C.J., Ed.), Westview Press, Boulder: p. 11-39.

Mercuri, C. 2007, Apuntes sobre el conjunto lítico de la Quebrada de Urcuro (Provincia de Salta): Primera caracterización. La Zaranda de Ideas. Revista de Jóvenes Investigadores en Arqueología, 3: 9-19. (in Spanish) ("Notes on the lithic set of the Quebrada de Urcuro (Province of Salta): first characterization") URL: http://documentos.revistalazaranda.com.ar/La-Zaranda-3-2007.pdf

Mercuri, C. 2008, El conjunto lítico de Quebrada Alta-Estructura 1: Primeros pastores de Santa Rosa de los Pastos Grandes, Puna de Salta. Intersecciones en Antropología, 9: 187-196. (in Spanish) (“Quebrada Alta Estructura 1 Lithic Assemblages: Early Shepherds From Santa Rosa De Los Pastos Grandes, Puna Of Salta") URL: http://www.scielo.org.ar/scielo.php?script=sci_arttext\&pid=S1850373X2008000100014

Mercuri, C. \& Mauri, E. 2015, La ocupación humana en la Quebrada de Los Corrales (Tucumán, Argentina) hacia el $1^{\circ}$ milenio de la era Cristiana: Análisis del material lítico de PV2 Estructura 1. Cuadernos del Instituto Nacional de Antropología y Pensamiento Latinoamericano - Series Especiales, 2: 122-128. (in Spanish) ("The human occupation in the Quebrada de Los Corrales (Tucumán, Argentina) towards the 1st millennium of the Christian era: analysis of the lithic material of PV2 Structure 1")

Míguez, G., Coronel, J.F. \& Martínez, J.G. 2015, Primer registro prehispánico de obsidianas en el piedemonte meridional de la Provincia de Tucumán (Argentina): Analisis tecnológico y de procedencia. Revista del Museo de Antropología, 8: 45-50. (in Spanish) ("First pre-Hispanic record of obsidian in the southern foothill of the Tucuman province (Argentina): technology and provenance analysis")

URL: https://revistas.unc.edu.ar/index.php/antropologia/article/view/11462

Montegú, J. 2018, Rocas, tecnología y vida aldeana durante el primer milenio de la Era en Anfama (Dto. Tafí Viejo, Tucumán, Rep. Argentina) at the Facultad de Filosofía y Humanidades, Universidad Nacional de Córdoba, Córdoba, 237 p. (in Spanish) ("Rocks, technology village life in the first millennium of the C. E. in Anfama (Dt. Tafí Viejo, Tucumán, Rep. Argentine)") URL: https://www.academia.edu/36493026

Moreno, E. 2005, Artefactos y prácticas. Análisis tecno-funcional de los materiales líticos de Tebenquiche Chico 1 at the Escuela de Arqueología, Universidad Nacional de Catamarca, San Fernando del Valle de Catamarca, 226 p. (in Spanish) (“Artifacts and practices. Techno-functional analysis of the stone materials of Tebenquiche Chico 1") URL: https://www.academia.edu/932679 
Nielsen, A.E. 2006a, Estudios internodales e interacción interregional en los Andes circumpuneños: Teoría, método y ejemplos de aplicación. In: Esferas de interacción prehistóricas y fronteras nacionales modernas: Los Andes sur centrales (Lechtman, H., Ed.), Instituto de Estudios Peruanos/Institute of Andean Research, Lima: p. 29-69. (in Spanish) ("Internodal studies and interregional interaction in the circumpune Andes: theory, method and application examples") URL: https://www.academia.edu/1047592

Nielsen, A.E. 2006b, Pobres Jefes: Aspectos corporativos en las formaciones sociales preIncaicas de los Andes circumpuneños. In: Contra la Tiranía tipológica en arqueología. Una visión desde Sudamérica (Langebaek, C. \& Gnecco, C., Eds.), Ediciones Uniandes, Bogotá: p. 121-150. (in Spanish) ("Poor Chiefs: Corporate Aspects in the Pre-Inca Social Formations of the Andes Circumpuneños")

URL: https://www.academia.edu/1047608

Palma, J. \& Olivera, D. 1992, Hacia una contrastación de un modelo arqueológico para el Formativo regional en Humahuaca: El caso de Estancia Grande. Cuadernos del Instituto Nacional de Antropología y Pensamiento Latinoamericano, 14: 237-259. (in Spanish) ("Towards a contrast of an archaeological model for the regional Formative in Humahuaca: the case of Estancia Grande") URL: http://revistas.inapl.gob.ar/index.php/cuadernos/article/view/432

Salazar, J. 2006, El espacio domestico en el Poblado Estratégico Los Cardones (valle de Yocavil, Tucumán) at the Facultad de Filosofía y Humanidades, Universidad Nacional de Córdoba, Córdoba, 141 p. (in Spanish) ("The domestic space in Los Cardones Strategic Village (Yocavil Valley, Tucumán)”)

Salazar, J. 2010, Reproducción social doméstica y asentamientos residenciales entre el 200 y el 800 d.C. en el valle de Tafí, Tucumán at the Facultad de Filosofía y Humanidades, Universidad Nacional de Córdoba, Córdoba, 305 p. (in Spanish) ("Domestic social reproduction and residential settlements between 200 and $800 \mathrm{CE}$ in the Tafi Valley, Tucumán")

Salazar, J., Franco Salvi, V.L., Berberián, E.E. \& Clavero, S.F. 2007, Contextos domésticos del Valle de Tafí, Tucumán, Argentina (200-1000 AD). Werken, 10: 25-47. (in Spanish) ("Domestic contexts of the Tafí Valley, Tucumán, Argentine (200-1000 CE)")

Somonte, C. 2009, Tecnología lítica en espacios persistentes de Amaicha del Valle (Tucumán) at the Facultad de Filosofía y Letras, Universidad de Buenos Aires, Buenos Aires, 411 p. (in Spanish) ("Lithic technology in persistent spaces of Amaicha del Valle (Tucumán)") URL: http://repositorio.filo.uba.ar/handle/filodigital/1295

Sullivan, A. \& Rozen, K.C. 1985, Debitage analysis and archaeological interpretation. American Antiquity, 50: 755-779. doi:10.2307/280165

Wynveldt, F. \& Flores, M. 2014, La obsidiana en el paisaje tardío del Valle de Hualfín (departamento de Belén, provincia de Salta). Arqueología, 20: 169-192. (in Spanish) ("The obsidian in the late landscape of Hualfín Valley (Departament of Belén, Catamarca Province)") URL: http://revistascientificas.filo.uba.ar/index.php/Arqueologia/article/view/1586

Yacobaccio, H., Escola, P., Lazzari, M. \& Pereyra, F. 2002, Long-distance obsidian traffic in Northwestern Argentina. In: Geochemical evidence for long-distance exchange (Glascock, M., Ed.), Bergin and Garvey, Wesport, Connecticut: p. 167-204. URL: https://www.researchgate.net/publication/236850377 
Yacobaccio, H., Escola, P., Pereyra, F., Lazzari, M. \& Glascock, M. 2004, Quest for ancient routes: obsidian sourcing research in Northwestern Argentina. Journal of Archaeological Science, 31: 193-204. doi:10.1016/j.jas.2003.08.001 